\title{
DIPLOMASI DIGITAL DAN IMPLEMENTASI APLIKASI SAFE TRAVEL DI KEMENTERIAN LUAR NEGERI
}

\author{
Andela Anggleni ${ }^{1)}$ \\ 1)Sekolah Tinggi Ilmu Administrasi (STIA) Satya Negara Palembang \\ J1. Sukatani 3, 8 Ilir Kecamatan Ilir Timur II, Kota Palembang, \\ Sumatera Selatan 30961
}

\begin{abstract}
Abstrak
Teknologi Informasi dan Komunikasi Berbasis Layanan Publik, Lingkungan Elektronik/Pilar Warga (e-RT / RW) (Studi e-Government di Kelurahan Talang Semut Kecamatan Bukit Kecil Kota Palembang). Studi ini didasarkan pada cara baru untuk mengelola layanan manajemen berorientasi sektor publik untuk masyarakat maju, daripada kepentingan pemerintah. Program EGovernment adalah program e-RT / RW Surabaya. Hasil penelitian menunjukkan program e-RT / RW yang bersumber dari Walikota Palembang. Faktor pendukung program e-RT / RW di Kelurahan Talang Semut, Bukit Kecil, Palembang adalah dukungan penuh dari pemerintah dan pihakpihak terkait, standar pelayanan dasar dan infrastruktur memenuhi syarat. Sedangkan faktor penghambatnya adalah kepentingan publik, kurangnya dukungan pihak internal, dan kurangnya pemeliharaan infrastruktur. Dari penelitian tersebut, para peneliti menyarankan bahwa sosialisasi yang diperlukan lebih sulit, tetapi tidak hanya sosialisasi tetapi juga pelatihan kepada orang untuk beroperasi secara online. Akuntabilitas keuangan yang transparan. Mengadakan forum komunikasi yang intens, penambahan konten situs web, dan kontrol masalah teknis dengan evaluasi menyeluruh.
\end{abstract}

Kata Kunci: e-Government, programs, e-RT/RW

\begin{abstract}
Public Service-Based Information Technology and Communication (ICT), Electronics Neighborhood/Pillars of Citizens (e-RT/RW) (Study of e-Government in Kelurahan Talang Semut Kecamatan Bukit Kecil Kota Palembang). This study is based on the new way to manage public sector-oriented management services to the community forward, rather than the interests of the government. E-Government Program is a program of $e-R T / R W$ Surabaya. The results showed the program e-RT/RW sourced from Palembang Mayor Factors supporting the program e-RT/RW in the Kelurahan Talang Semut, Bukit Kecil, Palembang is the full support of the government and relevant parties, the basic service standards and infrastructure are qualified. Whereas the inhibiting factor is the public interest, a lack of internal party support, and lack of maintenance of infrastructure. From the research, the researchers suggest that the necessary socialization harder, but not merely socialization but also training to people to operate online. Transparent financial
\end{abstract}


accountability. Holding intense communication forum, addition of website content, and control of technical problems with a thorough evaluation.

Keywords: e-Government, programs, e-RT/RW

\section{PENDAHULUAN}

Perkembangan paradigma administrasi publik dalam mengantisipasi kemajuan TIK misalnya kemajuan elektronik berbasis internet. Model ini, diharapkan dapat membantu organisasi pemerintah untuk menyediakan pelayanan publik berupa produk dan jasa dengan harga yang lebih rendah, meningkatkan efisiensi, pengurangan biaya produksi serta dapat meningkatkan kerja sama/koordinasi baik antar pemerintah dengan masyarakat, pemerintah dengan pihak swasta maupun antar pusat dan daerah.

Kota Palembang sendiri, telah berupaya mengitegrasikan sistem $e$ government melalui perubahan dari sistem kerja yang konvensional menjadi sistem kerja berbasis TIK. Kemudian penggunaan sambungan internet nirkabel misalnya, sudah digunakan di berbagai tamantaman di kota Palembang. Selain itu, pada tahun 2009, pemerintah kota Palembang telah melaksanakan program Palembang Broadband Citizen, yaitu pemasangan titik hot spot di area - area tertentu contohnya di Kambang Iwak. Pada tahun yang sama dilaksanakan juga pelatihan berbasis internet untuk 1000 orang pegawai untuk melaksanakan program tersebut.

Sehubungan dengan hal itu, pemerintah kota Palembang memahami bahwa pada akhirnya pencapaian visi Palembang yang melek IT akan bertumpu pada sejauh mana pencapaian yang diraih dari pelaksanaan program e-RT/RW di Kota Palembang. Berbagai aplikasi-aplikasi e-government dalam bentuk sistem informasi diharapkan dapat mengakomodasi kebutuhan komunikasi baik antara pemerintah dengan masyarakat, maupun dalam dunia usaha. Maka dari itu, diperlukan aplikasi-aplikasi yang berbasis teknologi informasi dan komunikasi yang memadai serta internet untuk pengolahan dan 
petukaran informasi dari berbagai stakeholder. Diharapkan berbagai pihak yang memerlukan terlebih masyarakat mendapatkan pelayanan yang lebih baik dan pemerintah juga mendapat feedback masyarakat berupa masukan dan informasi dari masyarakat.

Pemanfaatan teknologi informasi dalam e-government umumnya dipakai untuk mengolah data, mencakup proses, mendapatkan, menyusun, menyimpan, dan memanipulasi data dalam berbagai cara untuk menghasilkan informasi yang berkualitas, akurat, tepat waktu, dan dapat dipertanggung jawabkan yang digunakan demi kepentingan publik yang dapat dimanfaatkan dalam pengambilan keputusan.

Peran media internet merupakan entitas dari bentuk teknologi informasi yang memungkinkan pemerintah agar berinteraksi secara langsung dengan masyarakatnya tanpa terkendala ruang dan waktu.. Berdasarkan uraian diatas setidaknya ada dua rumusan masalah yaitu, 1) Bagaimana pemanfaatan program e-RT/RW di Kelurahan Talang Semut Kecamatan Bukit Kecil kota Palembang? 2) Apa saja faktor penghambat dan faktor pendukung dalam menerapkan program eRT/RW di Kelurahan Talang Semut Kecamatan Bukit Kecil kota Palembang?. Tujuan penelitian ini ialah mendeskripsikan pelayanan program eRT/RW dalam rangka mewujudkan masyarakat Palembang yang cakap TIK, kemudian untuk mengetahui dan menganalisis layanan program e-RT/RW dan untuk mengetahui dan menganalisis faktorfaktor penghambat dan faktor-faktor pendukung dalam menerapkan program e-RT/RW.

E-Government sering dideskripsikan secara beragam oleh masingmasing-masing individu atau institusi. Dalam cakupan negara, pemahaman mengenai konsep e-government di suatu negara tidak dapat dipisahkan dengan kondisi internal dari negara yang bersangkutan. Menurut World Bank yang dikutip oleh Setyadi (2003) mendefinisikan e-government yang mana dapat berarti bahwa e-government mengacu pada pemanfaatan TIK oleh institusi pemerintah, seperti Wide Area Network, Internet, Mobile Computing, yang 
selanjutnya dapat mendukung transformasi hubungan dengan warga negara, pelaku bisnis, dan institusi pemerintah lainnya.

Pemanfaatan teknologi informasi ini bertujuan untuk menyelenggarakan pelayanan publik yang lebih baik, meningkatkan hubungan antara pemerintah dengan bisnis serta industri, memberdayakan masyarakat melalui akses terhadap informasi, serta meningkatkan efisiensi manajemen pemerintahan. Keuntungan lain dari pemanfaatan teknologi informasi oleh institusi pemerintah diantaranya dapat mengurangi korupsi, meningkatkan transparansi, meningkatkan kenyamanan, meningkatkan pendapatan, dan atau dapat mengurangi biaya.

Definisi pelayanan publik menurut Hidayaningrat dikutip oleh Suwondo (2001, h.29) menjabarkan pelayanan publik sebagai aktivitas yang dilakukan untuk memberikan jasa-jasa dan kemudahan bagi masyarakat untuk memegang teguh syarat-syarat efisiensi, efektivitas, dan penghematan.

Sedangkan seperti yang dikemukakan Siagian (1992, h.131) berpendapat bahwa pelayanan publik adalah aktivitas yang dilakukan untuk memberikan jasa-jasa dan kemudahan kepada masyarakat dengan mempertimbangkan aspek-aspek sebagai berikut: a. Pelayanan publik berhubungan dengan kegiatan memberikan pelayanan kepada masyarakat sesuai dengan haknya, b. Pelayanan yang diberikan berupa barang dan jasa yang vital, c. Adanya prinsip-prinsip efisiensi, efektivitas dan penghematan dalam memberikan pelayanan kepada masyarakat.

Paradigma pelayanan publik berkembang dengan fokus pengelolaan yang berorientasi pada kepuasan pelanggan (customer-driven government), hal ini sejalan dengan perkembangan penyelenggaraan Negara dalam rangka mewujudkan pelayanan yang prima dan berkualitas.

Prinsip-prinsip pelayanan publik digunakan sebagai upaya peningkatan kualitas di dalam penyediaan pelayanan pada sektor publik termasuk dalam hal ini adalah sebagai dasar pengembangan e-government. tersebut ialah prinsip aksesibilitas, kontinuitas, teknikalitas, profitabilitas, dan akuntabilitas. 
Jenis-jenis pelayanan publik menurut LAN diantaranya adalah pelayanan pemerintahan, pelayanan pembangunan, pelayanan utilitas, pelayanan sandang, pangan dan papan, pelayanan kemasyarakatan. Di dalam pelaksanaanya, pemberian pelayanan oleh pemerintah kepada masyarakat dapat dilakukan melalui beberapa pola. Pola-pola di dalam memberikan pelayanan publik dijelaskan pula oleh LAN yaitu pola pelayanan teknis fungsional, pola pelayanan satu pintu, pola pelayanan satu atap, pola pelayanan terpusat, dan pola pelayanan elektronik.

Chester Barnard, yang dikutip dalam Kebijakan Kinerja Karyawan menurut Prawirosentono, (1999, h.28), pengertian efektif dan efisien dikaitkan dengan sistem kerjasama yakni dalam organisasi perusahaan atau lembaga pemerintahan.

Efisiensi, efektifitas dan transparansi merupakan unsur vital dalam mewujudkan eGovernment, sehingga e-Government sangat sejalan dengan usaha untuk mewujudkan pemerintahan yang baik (good governance). Disamping itu, e-Government diharapkan dapat mendukung tata kelola, produktivitas dan efisiensi dalam instansi pemerintahan dalam peningkatkan pertumbuhan ekonomi. Dengan demikian, untuk menghadapi era global ini Pemerintah Daerah dituntut untuk membangun komitmen di segala bidang.

Partisipasi masyarakat seperti yang dikemukakan Abu Huraerah, (2008) membagi jenis-jenis partisipasi sebagai berikut:
a. Partisipasi buah pikiran,
b. Partisipasi tenaga,
c. Partisipasi harta benda,
d. Partisipasi keterampilan dan kemahiran,
e. Partisipasi sosial.

\section{METODE PENELITIAN}

Penelitian ini berupaya mendeskripsikan, menguraikan, menginterpretasikan permasalahan dan kemudian mengambil kesimpulan dari 
permasalahan tersebut yang disajikan dalam bentuk tulisan secara sistematis tentang pelayanan Pemerintah Kota Palembang dalam program e-RT/RW.

Instrumen penelitian merupakan alat bantu yang digunakan untuk menggali data dalam penelitian, sehingga kegiatan penelitian dapat berjalan dengan baik dan lancar. Instrumen yang digunakan adalah sebagai berikut :

1. Peneliti sendiri, yaitu dengan menggunakan panca indra untuk menyaksikan secara langsung fenomena-fenomena yang diteliti.

2. Pedoman wawancara (interview guide)

3. Catatan lapangan, berisi tentang pokok-pokok informasi yang diperoleh selama peneliti melakukan wawancara dan observasi.

\section{PEMBAHASAN}

\section{Aspek Kebijakan}

E-government untuk pelayanan masyarakat. Jajaran Pemerintah Kota Palembang dengan PT. Telkom Divre V Palembang melaksanakan kerja sama yang ditandai dengan adanya penandatanganan MoU, Jum"at pada 23 April 2010, ditandatangani oleh Walikota Palembang dan GM Consumer Service PT. Telkom Area Palembang, hal ini berkaitan dengan pembangunan infrastruktur eRT/RW.

MoU adalah untuk menggenjot peningkatan internet khususnya warga Kota Palembang. E-RT/RW kemudian diharapkan mampu meningkatkan pelayanan informasi TIK, dan sebagai penghubung antara warga ke Pemerintah Kota Palembang.

\section{Kepemimpinan dan Organisasi}

Sebenarnya keinginan untuk mengembangkan tata kelola suatu organisasi bukan hal baru, pemanfaatan IT seperti layanan pengaduan masyarakat berbasis sms, e-sapawarga pun demikian, yang mana semua layanan tersebut terpublish di web pusat pemerintah daerah, sekaligus dapat digunakan sebagai alat untuk meninjau, monitoring dan evaluasi kinerja khususnya lingkup Pemerintah tingkat satuan kerja perangkat daerah (SKPD). 


\section{Pengembangan Perancanaan Program dan Pemantauan Layanan.}

Dengan sapawarga ini, informasi tentang proyek di tiap wilayah/ Laporan yang masuk pada tahun pertama sejak launching pada 28 November 2011 sebanyak 698 keluhan. Pada 2012, tercatat 2.717 keluhan, meningkat menjadi 4.176 keluhan pada 2013 ada tahun 2013, dan pada 2014 sebanyak 4.298 keluhan.

\section{Pendanaan}

Pada program e-RT/RW, dalam penyusunan sistem anggaran dilakukan dengan e-budgeting. Di dalamnya mencantumkan berapa besar biaya perjalanan dinas dan kebutuhan operasional lainnya. dengan e-budgeting, penyusunan anggaran dinas dapat ditekan hingga tiga hari saja. Setiap bulan akan dilakukan evaluasi apa penyebab keterlambatannya.

Namun, terdapat kendala pada pelaksanaannya, yaitu masyarakat belum dapat mengakses e-budgeting secara maksimal. Penerapan $e$ government setidaknya terdiri dari tiga bagian, yaitu langkah publikasi, interaksi, dan transaksi seperti yang dikutip Howard (2001).

\section{Partisipasi Publik terhadap layanan eRT/RW di Kelurahan Talang Semut Kecamatan Bukit Kecil Kota Palembang}

Terdapat beberapa bentuk partisipasi yang terlibat. Yang pertama adalah partisipasi dalam pengambilan keputusan, beberapa keputusan strategis diambil setelah diadakan musyawarah seperti respon untuk keluhan masyarakat, keperluan administrasi, dan layanan lainnya. Kedua, partisipasi langsung, partisipasi representatif, dan partisipasi dalam bentuk dukungan berupa keterlibatan mental.

Kedua, partisipasi langsung dalam kegiatan bersama secara fisik dan tatap muka, yang tercermin dengan adanya pelatihan, sosialisasi, dan sebagainya.

Ketiga, Partisipasi representatif, ini adalah jenis partisipasi dalam bentuk mandat kepada wakil-wakil yang duduk dalam organisasi atau panitia. 


\section{Pemanfaatan Program e RT/RW di Kelurahan Talang Semut, Kecamatan Bukit Kecil Kota Palembang}

Adapun Pemanfaatan dalam program eRT/RW yang bisa diakses masyarakat Kelurahan Talang Semut, Kecamatan Bukit Kecil, antara lain meliputi:

(1) Pertemanan, sebagai situs jaringan pertemanan sosial, tentunya salah satu kelebihan dari sapa warga yaitu untuk dapat menjalin pertemanan atau persaudaraan antar warga Surabaya. Sehingga dalam situs ini terdapat menu (teman) yang dalamnya, pengguna bisa mencari data mengenai teman atau untuk menambah teman.

(2) E-toko, Konten ini digunakan untuk melakukan kegiatan ekonomi (khususnya bagi UKM) pengguna dapat mengiklankan barang dagangannya dan pembeli dapat memperoleh informasi mengenai produk yang akan dibelinya.

(3) E-government, konten ini digunakan untuk menambah wawasan atau pengetahuan bagi pengguna, karena di dalamnya terdapat:

a. Berita tentang Kota Palembang secara keseluruhan

b. Tentang pengadaan barang dan jasa

c. Sebagai sarana mendapat informasi berupa masukan terhadap proyek yang sedang berlangsung di daerah pengguna. Dengan member para ketua RT dan RW dapat langsung melaporkan secara tepat waktu ke situs sapawarga.palembang.go.id Info tersebut akan otomatis tersampaikan ke akun SKPD terkait, misalnya sebagai penanggung jawab proyek tertentu.

d. Mengetahui kebutuhan komunikasi kesehatan Indonesia pada umumnya dan komunitas kesehatandi ruang lingkup Kota Palembang khususnya.

e. Untuk menambah pengetahuan dan menjadi sarana belajar bagi siswa SD, SMP, SMA, SMK. 
f. Melaporkan secara real time jika ada kejadian awal wabah penyakit atau anak putus sekolah karena orang tuanya mendadak miskin dengan meneruskan laporan warga.

g. Administrasi RT/RW. dikembangkan untuk kecepatan dan ketepatan pengurusan administrasi RT/RW. Konten ini dapat memudahkan baik bagi warga, RT maupun RW untuk mengurus kegiatan administrasi.

\section{Faktor pendukung dan faktor penghambat dalam pemanfaatan program e-RT/RW di Kelurahan Talang Semut, Kecamatan Bukit Kecil Kota Palembang}

(a.) Faktor Pendukung Ada tiga elemen suskes yang harus dimiliki dalam mengembangkan konsep digital di sektor publik yaitu Support, Capacity, dan Value.

(b.) Faktor Penghambat Adanya faktor penghambat program ini antara lain; kurang antusiasnya masyarakat Kelurahan Talang Semut, Kecamatan Bukit Kecil Kota Palembang, kurangnya Internal Support, dan terbatasnya sarana dan prasarana. Kurang antusias masyarakat terlihat dari hanya anakanak muda saja yang memanfaatkan program ini, dan pada sosialisasi selain kurangnya jumlah masyarakat yang hadir, peserta yang hadir juga cenderung pasif. Sedangkan dari internal sendiri hanya fasilitas yang disediakan cenderung terkesan seadanya. Kemudian dari beberapa fasilitas yang ada juga beberapa didapati dalam keadaan tidak berfungsi ataupun rusak, sehingga menghambat masyarakat untuk praktik menggunakan layanan secara online.

\section{KESIMPULAN}

Pemanfaatan program e-RT/RW di Kota Palembang dapat dikatakan sudah baik, yang pelaksanaan programnya berasal dari pemerintah selaku regulator dan pemberi fasilitas, yang didukung dengan faktor pengembangan konsep digital. Namun, juga ada beberapa faktor penghambat seperti 
kurangnya animo masyarakat, kurangnya internal support, serta sarana dan prasana yang perlu diadakan pembenahan. Selain itu, perlu diadakan forum forum komunikasi yang intens di seluruh lapisan elemen masyarakat, kemudian tidak hanya sekedar sosialisasi, hendaknya kemudian disertakan pula simulasi atau praktek agar masyarakat lebih mengerti lagi penggunaan layanan secara online ini dan juga hendaknya memperhatikan aspek evaluasi secara menyeluruh, tidak hanya memperhatikan berdasarkan dari keluhan masyarakat, namun juga dari aspek program dan layanan itu sendiri.

\section{DAFTAR PUSTAKA}
A. Buku

Barnard, Chester. (1999). Kebijakan Kinerja Karyawan, Cambrigde Mass, Harvard University Press.

Handayaningrat, S. (1988). Administrasi Negara Baru. Jakarta, LP3ES.

Lembaga Administrasi Negara. (2003). SANKRI: Buku 1 Prinsip-Prinsip Penyelenggaraan Negara. Jakarta, Perum Percetakan Negara RI.

Moenir. (1998). Manajemen Pelayanan Umum di Indonesia, Jakarta, Bumi Aksara.

Siagian, S.P. (1992). Organisasi Kepemimpinan \& Perilaku Administrasi. Jakarta, Rineka Cipta.

Surat Keputusan Walikota Surabaya Nomor 188.45/224/436.1.2/2010. Surabaya, Pemerintah Kota Surabaya.

Suwondo. (2001). Peserta Pelayanan Publik: Hubungan Komplementer Antara Sektor Negara, Mekanisme Pasar dan Organisasi. Jakarta, Bumi Aksara

B. Lain-lain (Dokumen, Jurnal, dan Majalah)

Bank Dunia. (2002). E*Government: A Defintion of $E^{*}$ Government. (http//www.worldbank.org/publicsector/egov/definition.htm>) [Diakses pada 2 Juni 2014].

Keamanan Database. Information Security Management System. [online] http:/ /www.dqsindonesia.com/90-iso-product/our-product/154-iso27001-keamanandata.html. (Diakses pada 18 Agustus 2014). 